\title{
5. Sınıf Sosyal Bilgiler Dersinde Drama Yönteminin Kullanılmasına İlişkin Öğrenci Görüşleri ${ }^{1}$ *
}

\author{
Feyzullah EZER \\ Dr. Öğr. Üyesi, Frrat Üniversitesi, Eğitim Fakültesi, \\ Türkçe ve Sosyal Bilimler Eğitimi Bölümü, \\ Sosyal Bilgiler Eğitimi Ana Bilim Dalı \\ fezer@firat.edu.tr \\ Orcid ID: https://orcid.org/ 0000-0002-5862-8541
}

\author{
Selda AKSÜT \\ Doktora Öğrencisi, Fırat Üniversitesi, Eğitim Bilimler Enstitüsü, \\ Türkçe ve Sosyal Bilimler Eğitimi Bölümü, Sosyal Bilgiler Eğitimi Bilim Dalı \\ selda.aksut@hotmail.com \\ Orcid ID: https://orcid.org/0000-0001-6128-7867
}

\begin{abstract}
Öz
Araştırmanın amacı ortaokul beşinci sınıf Sosyal Bilgiler dersi "Bölgemizi Tanıyalım" ünitesinde yer alan konuların öğretiminde drama yönteminin nasıl kullanılabileceğine ilişkin drama etkinlikleri oluşturmak, oluşturulan drama etkinliklerinin öğrenciye etkisini araştırmak ve yöntem ile ilgili yapılan uygulamalara ilişkin öğrencilerin görüşlerini belirlemektir. Araştırma, nitel araştırma yaklaşımına uygun olan eylem araştırması ile yürütülmüştür. Araştırmanın çalışma grubunu 2013-2014 eğitim öğretim yılı Elazı̆̆ il merkezinde 5. sınıfta öğrenim gören 38 öğrenci oluşturmaktadır. Çalışma grubu amaçsal örnekleme yöntemlerinden biri olan kolay ulaş1labilir durum örnekleme ile belirlenmiştir. Araştırma verileri görüşme yöntemi ile yarı yapılandırılmış görüşme formu kullanılarak elde edilmiştir. Araştırmada elde edilen verilerin

\footnotetext{
${ }^{1}$ Makale Geliş/Kabul Tarihi: 17.01.2020 / 14.07.2020

* Bu çalışma Selda Aksüt tarafından Feyzullah Ezer danışmanlığında Fırat Üniversitesi Eğitim Bilimleri Enstitüsünde hazırlanan "5. Sınıf Sosyal Bilgiler Dersinde Drama Yönteminin Öğrenci Başarısına, Tutumuna ve Kalıcılı̆̆a Etkisi” başlıklı yüksek lisans tezinden türetilmiştir.

Künye Bilgisi: Ezer, F. ve Aksüt, S. (2020). 5. Sinvf Sosyal Bilgiler Dersinde Drama Yönteminin Kullanılmasina İliş̧kin Öğrenci Görüşleri. Kahramanmaraşs Sütçü İmam Üniversitesi Sosyal Bilimler Dergisi, 17 (2), 625-651. DOI: 10.33437/ksusbd.676737
} 
çözümlenmesinde içerik analizi yöntemi kullanılmış ve verilerin değerlendirilmesi için nitel veri analiz programından yararlanılmıştır.

Araştırma sonucunda öğrencilerin drama yönteminde uygulamanın faydalarını konuyu öğrenme, özgüven, eğlenceli öğrenme ortamı, Sosyal Bilgiler dersine ilgi, birlik beraberlik ve kalıcı öğrenme şeklinde ifade ettikleri belirlenmiştir. Sosyal Bilgiler öğretmenlerin bu çağdaş öğretim yöntemini kullanmasının faydalı olacağı önerisinde bulunulabilir. Ayrıca bu yöntemin farklı derslerde, sinıf seviyelerinde kullanılması ve sinıf ortamlarının uygulamalara uygun olarak düzenlemesi önerilebilir.

Anahtar Kelimeler: Drama Uygulamaları, Drama Yöntemi, Sosyal Bilgiler Öğretimi.

\title{
Student Views On The Use Of Drama Method In 5th Grade Social Studıes Course
}

\begin{abstract}
The objective of the present study is to construct drama activities related to the use of drama method in the instruction of topics in the middle school fifth grade Social Studies course, "Learning About Our Region" unit, and to investigate the effect of the drama activities on student the course and to determine the student views on the applications of the method. The action research, a qualitative research approach, was used in the study. The study was conducted with 38 students the fifth grade in located at Elazığ city center during 2013-2014 academic year fall semester. The study group was selected with convenience sampling, a purposive sampling method. An interview form was used as the data collection instrument. Content analysis method was used to analyze the research data and qualitative data analysis software was used.

As a result of the research, it was determined that the students expressed the benefits of the application in the drama method as learning about the subject, selfconfidence, fun learning environment, interest in the Social Studies course, unity and permanent learning. It can be suggested that it would be beneficial for teachers to use this modern teaching method. It was also proposed to use this method in different courses and grade levels and to rearrange the classroom environment appropriately for the applications.
\end{abstract}




\section{F.Ezer-S.Aksüt $\quad$ 5. Sınıf Sosyal Bilgiler Dersinde Drama Yönteminin...}

Keywords: Drama Practices, Drama Method, Social Studies Education.

\section{GíRIŞ}

Drama, insanın düşündüklerini harekete dönüştürebileceği bir yoldur (Gönen ve Dalkılıç, 2000: 23). Drama, tiyatro sahnesine çıkmadan ve oyunda belli rollere bağlı kalmadan oynayıp hayat tecrübelerini geliştirmek ve öğrenmektir (Karadağ ve Çalışkan, 2008: 40-41). Drama hayattaki durumları, olayları doğrudan ve birden canlandırmaktır. Canlı ve cansız varlıkların sözlü veya sözsüz olarak taklit edilmesi ya da bir durumun, bir eylemin ya da bir hissin yeniden yaratılmasıdır. Bir anlamda drama hayali oyundur (Dirim, 1998: 34). Drama öğrencilerin bir deneyimi, bir konuyu, bir kavramı, bir durumu, bir beceriyi, bir varlığ 1 pandomim, eğitsel oyun, dramatizasyon, doğaçlama ve rol oynama gibi teknikler uygulayarak canlandırma süreci olarak tanımlanabilir (Cin, 2006: 141).

Çocukluk döneminde oynanan oyunlar çocuğun yaşam biçimidir. Çocukluk döneminin diğer bir ismi oyun çağıdır. Çocuklar, sosyal ortama oyunla girmeye başlar. Zevk alarak geçirdikleri zamanı en mutlu anı olarak zihinlerine kaydederler (Morgül, 2003: 13-14). Çocukların oynadıkları evcilik, doktorculuk ve bakkalcılık gibi oyunlarda rol yapma, kişileri canlandırma ve kılık değiştirme gibi etkinliklerin olması oyunların dramatik özellik taşımasını sağlar ve dramanın özünde oyun bulunmaktadır. Drama ve oyun iç içedir. Çocuk drama faaliyetleri sırasında hem oyun oynar hem de çoğu kavram, konu ve sosyal davranışı daha kalıcı olarak öğrenme firsatı bulur (Ö̈meroğlu, Ersoy, Tezel Şahin, Kandır ve Turla, 2003: 16).

Drama yönteminin birçok tanımı ve türü bulunurken bunlar içerisinde en fazla kullanılanlar yaratıcı drama, eğitici drama, psikodrama ve sosyodramadır (Karadağ ve Çalışkan, 2008: 50). Katılımcıların yaşam tecrübelerinden başlayarak, bir amacın ve fikrin, doğaçlama, rol oynama (rol alma), pandomim vb. tekniklerden faydalanarak dramatize edilmesidir. Bu drama süreçleri tecrübeli bir lider eşliğinde uygulanırken kendiliğinden (spontaniteye), şimdi ve burada ilkesine, -mış gibi yapmaya dayalı olan yaratıcı drama, oyunun genel özelliklerinden doğrudan faydalanır (Adıgüzel, 2014: 43). Eğitici drama, olabildiğince esnek olmanın yanı sıra, esas kuralları dışarıdan ve daha önceden tespit edilmiş, bir grup içinde yaşanan, yetişkin bir lider (örneğin bir öğretmen) tarafından rehber olunan veya başlatılan ve çocukların bir grup oyunu gibi algıladıkları etkinlikler bütünüdür (Önder, 2012: 6-7). Aslında bir tedavi yöntemi olan psikodrama kişilerin problemlerini anlatmayıp canlandırdığı, temelinde "rol oynama” olan bir yöntemdir (Adıgüzel, 2014: 322). Sosyal problemlerle ilgili gerçekleştirilen canlandırma faaliyetlerinin yapıldığı sosyodrama psikolojik 
danışma ve rehberlik hizmetlerinde kullanılan teknikler arasında sayılır (Karadağ ve Çalışkan, 2008: 53).

Dramada öğrencilerin yaparak, eğlenerek öğrenmelerini sağlayan ve onları öğrenmeye karşı motive eden yöntem ve tekniklere yer verilmiştir. Bunlar; rol oynama, doğaçlama, dramatik oyun, pandomim (sözsüz oyun), zihinde canlandırma, kukla, benzetim, rol değiştirme, oyun yaratma (yaratıcı dramatizasyon), geriye dönüş, paralel çalışma, yaratıcı dans, öykünme (taklidi oyun), kenardan (dışarıdan) yönlendirme, bilinç koridoru, öykü olay canlandırma ve dedikodu halkası olarak siralanabilir (Erden, t.y.: 138 ).

Drama, çocuğun empati kurarak ve çok yönlü düşünmesini sağlayarak, öğretimde kendisini rahat ifade edebilmesini, pasif olmamasını ve hayal gücünü kullanmasını sağlayan bir faaliyettir (Dirim, 1998: 35). Drama, üst düzeyde hayal gücüne dayanan bir yoldur. İnsanın kendisini ve başkalarını tanımasına dramatik etkinlikler destek olur. Drama öğrencilerin yetenek sahibi, sabırlı, istikrarlı, çok yönlü dünyayı algılayıp kendi dünyalarını genişletmeye çalışan, hayata kendi fikirleri ile katılan ve kendine güvenen bireyler olmaları yolunda yardımcı olur (Gönen ve Dalkılıç, 2000: 48). Drama faaliyeti, çocuğun çevresindeki insanlarla etkileşim içerisinde olumlu yaşantı geçirmesi gerektiğini öğrenmesine yardım eder (Önder, 2012: 51). Drama öğrencinin imgeleme ve düşünme gücünü aktif hale getiren bütünü oluşturmaya yönelik çalışmalardır. Bu çalışmalar öğrencinin anlama ve anlatma yeteneğini kullanmasına ve yeniliklere doğru ilerlemesine yardımc1 olur (Sünbül, 2007: 364). Drama faaliyeti ve süreç içerisinde çocuklar birçok bilgi öğrenirler. Bilgileri çocuklar diğerlerinin tecrübelerini seyrederek ya da farklı yaşanmışlıklarla elde edebilirler. Çocukların var olan bilgileri ile yeni edindiklerini karşılaştırarak yeni sonuçlar elde etmeleri muhakeme yeteneklerinin temelini oluşturur (Yayla Ceylan, 2014: 22).

Drama yöntemi ile işlenen derslerde aşamalar halinde devam eden planlı bir işleyişs söz konusudur. Isınma, uyum-güven, doğaçlama oluşumlar ve rahatlamadeğerlendirme şeklinde işleyiş gerçekleştirilir (Morgül, 2003: 20).

Eğitimde drama sürecinde yer alan öğeler çalışma mekânı (çevre, araç ve gereçler), oyun grubu (katılımcılar), çalışmanın kendisi (uygulama) ve drama lideri (öğretmen) olarak sıralanabilir (Çağdaş, Albayrak ve Cantekinler, 2003: 101). Uygulamanın yapılacağı uygulama alanı önemlidir. Uygulama alanları açık ve kapalı alanlar olabilir. Yaratıcı drama etkinlikleri için okulda bulunan salon, sınıf seçilebileceği gibi gezi, gözlem için açık alanlar da tercih edilebilir (Ömeroğlu vd., 2003: 83). Dramatik etkinliklerin uygulanması aşamasında drama eğitiminde kullanılan uygulama alanlarından farklı alanlar kullanılmayabilir. Uygulama alanı olarak sinıflar kullanılabilmektedir (Erbay, 2014: 44). Grupla yapılan bir uygulama olan drama da birlikte yaşama ve paylaşma süreci 


\section{F.Ezer-S.Aksüt $\quad$ 5. Sınıf Sosyal Bilgiler Dersinde Drama Yönteminin...}

yaşandığında zevk alınması için istekli kişilerin katılması gerekir (Çağdaş vd., 2003: 101). Sürecin başarılı olması bakımından, gruptaki üyelerin azami düzeyde ortak özelliklere sahip olması gerekir. Grup üyesi benmerkezcilikten çıkıp biz olmayı hedefleyen bir yaşantı geçirir. Kişi önce kendini sonrada diğer kişileri tanımaya çalışır. Ele alınacak duygu, hayallerin ve görüntülerin hepsi yaratıcı drama etkinliklerinde metni oluşturur (Adıgüzel, 2014: 80-96). Drama sırasında komutu ilk olarak veren, sunan, değerlendiren ve tekrar uygulayan kişi, dramanın lideridir. Drama da lider, drama çalışmalarında katılımcılara rehberlik eden kişidir (Çağdaş vd., 2003: 102). Lider her zaman sabırlı olmalı, drama grubuna güven vermeli, grubu anlamak için dinlemeli, grubun kontrolünü sağlamalı ve grubun üyelerine yardımcı olmalıdır. Kesinlikle taraf tutmamalı ve kimseyi incitmemelidir (Morgül, 2003: 18).

Drama etkinliklerinde hedeflenen sonuçların elde edilmesi ve koşulların ne kadarının yerine getirildiği drama etkinlikleri yapılırken dikkat edilmesi gereken koşullar ile ilgilidir. Bu koşullar dramanın yapısı, çevre, öğretmen katılımı, sessizlik, dramaya ayrılan süre, etkinlik seçimi ve gruplar arası farklılıklardır (Karadağ ve Çalışkan, 2008: 120).

Drama etkinliği yapmak için araç-gerecin olması şart değildir ancak araçgerecin olması çocuğun çağrışım yapmasını sağlayacaktır (Morgül, 2003: 39-40). Drama etkinliğinde kullanılan malzemeler dramanın ana konusu olabileceği gibi yardımcı öğe olarak da karşımıza çıkabilir. Kullanılan araç-gereçler dramaya katılan kişinin etkinlik süresince etkinlikten kopmasını engeller ve olayların içerisinde aktif bir şekilde kalmasını sağlar. Bu araç-gereçler uygulamayı yapan kişilerin var olan enerjilerinin, yaratıcılıklarının ortaya çıkmasını ve etkin kullanılmasını sağlamaktadır. Bu nedenle uygulama alanında yer almalıdır (Adigüzel, 2014: 88).

Günümüz eğitim anlayışında meydana gelen yenilikler, eğitim politikalarının da değişmesini mecburi hale getirmiştir. Bu mecburiyet; insana yapılan yatırımın düşünsel, bilimsel, sanatsal ve teknolojik yönlerini yani kültürel birikimini oluşturmaktadır. Bu birikim, günümüz ihtiyaçlarını karşılayan nitelikli kişilerin yetiştirilmesinin ön koşulu olan etkili ve verimli bir eğitim ile yaratılabilir. Geleneksel eğitim anlayışında öğretmen merkezli, çocukların ilgi, istek, yetenek ve gereksinimlerinin önem verildiği eğitim durumları yerine, bilgi aktarımına dayalı yöntem ve teknikler bulunmaktadır (Ömeroğlu vd., 2003:21-22). Eğitimde uygulanan drama yöntemi hem planlama hem de çalışma ve değerlendirme aşamalarında öğrenci merkezli eğitimi dikkate alır. Öğrenme süreci boyunca öğrencinin aktif katılımını sağlayarak, süreç boyunca eğlenceli zaman geçirmeleri ve öğretilenlerin kalıcı olması amaçlanmaktadır. Bu süreç içerisinde eğlenerek öğrenmenin gerçekleşmesi kalıcılığı arttırmaktadır (Gönen ve Dalkılıç, 2000: 75). 
Sosyal Bilgiler, insan ve toplumla ilgilenen diğer bilimlerin içerik ve yöntemlerini kullanarak, insanın çevresiyle ve kendisiyle olan etkileşimini belli bir zaman dâhilinde disiplinler arası bir yaklaşımla ele alan ve evrenselleşen bir dünyada yaşamla ilgili esas demokratik değerlerle donatılmış, düşünen ve becerili demokratik vatandaşlar yetiştirmeyi hedefleyen bir çalışma alanı olarak ifade edilebilir (Doğanay, 2005: 18-19). Sosyal Bilgiler, insan ilişkilerinden yola çıkarak, insanların içinde bulundukları çevreyle olan ilişkilerini inceleyen bilim olarak açıklanabilir (Barth ve Demirtaş, 1997: 16). Sosyal Bilgilerin amaçları; öğrencilere evrensel ve milli değerler ve sosyal kuruluşlar hakkında bilgiler vererek, bilgi, beceri, tutum ve değerler kazandırmak, öğrencilere içinde bulundukları toplumun sahip olduğu kültürel mirası ve değerleri aktararak, onların iyi birer vatandaş veya birey olmalarını sağlamak, öğrencilerin bireysel ve sosyal problemleri tanımlama, analiz etme ve karar verme süreçlerini geliştirmektir (Bilgili, 2006: 7).

İyi bir vatandaş yetiştirmek Sosyal Bilgiler dersinin temel amaçları arasında yer almaktadır. Problemleri çözmeyi, doğru karar vermeyi ve tecrübelerine dayanarak hayata aktif katılımı ön planda tutan bireylerin yetiştirilmesini sağlamak için ilköğretim Sosyal Bilgiler programı yenilenmiştir. Eski programlarda bilgi aktarımı söz konusu iken yenilenen program sayesinde bilginin yanında beceri ve değer kazandırma amaçlanmaktadır. Öğrencilerin derse aktif katılımıyla etkili bir Sosyal Bilgiler öğretimi sağlanmaktadır. Öğrencinin kendi deneyimlerini ve bireysel farklılıkların farkına vararak çevreyle etkileşime girmesini sağlayan aktif öğrenme yöntem ve tekniklerden faydalanılması gerekmektedir. Aktif öğretim yöntemleri eğitimde kullanılarak yeni ilköğretim Sosyal Bilgiler programının başarıya ulaşılması sağlanabilir. Programda da tavsiye edilen yöntemlerden biri de yaratıcı dramadır (Aladağ, 2009: 472).

Çocuklar aktif bir şekilde derse katıldığında, sosyal hayattaki deneyimleriyle detayları fark ederek sonuca daha çabuk varabileceklerdir. Yaşadığı dünyayı, çevresini gözlemleme, araştırma ve tanıma başarısını bu şekilde çocuk gösterecektir. Öğretimin temelini çocuğun öğrendiği bilgileri davranışlarına uygulaması ile teşkil edilmesi drama yolu ile gerçekleştirilebilir. Soyut kavramların yer tuttuğu Hayat Bilgisi ve Sosyal Bilgilerin tüm konularında başarıyı arttırmada drama etkinliği kullanılabilir (Karadağ ve Çalışkan, 2008: 99).

Sosyal yaşamda karşılaşılan durumların istenildiği anda tekrar dramatize edilmesi Hayat Bilgisi ve Sosyal Bilgiler dersinde drama yönteminin kullanılmasının sağlayacağı bir diğer faydadır. Bu sayede drama, öğrencilerin günlük hayatlarında karşılaşamayacakları durumları bizzat yaşayarak öğrenmelerine destek olur. Aynı zamanda öğrencilerin düşünme, algılama, 


\section{F.Ezer-S.Aksüt $\quad$ 5. Sınıf Sosyal Bilgiler Dersinde Drama Yönteminin...}

yorumlama, dinleme, ifade etme yeteneklerinin de verimli bir şekilde gelişmesine katkıda bulunur. Bu becerilerin kazanılması Hayat Bilgisi ve Sosyal Bilgiler dersinin öğrencilere kazandıracakları davranışlar arasında bulunmaktadır (Karadağ ve Çalışkan, 2008: 99).

Araştırmada soyut konuları içeren Sosyal Bilgiler dersinin öğrencilere en üst seviyede aktarılması, öğrencilerin derse aktif olarak katılıp konuyu kavramaları ve bu bilgilerin öğretimlerinin daha sonraki öğrenim aşamalarına aktarmalarında drama yönteminin önemi vurgulanmaktadır. Konunun yeterince önemli olmas1 bu araştırmayı önemli kılan bir sebeptir. Araştırma sonuçlarının Sosyal Bilgiler alanında çalışma yapan akademisyenlere, Sosyal Bilgiler öğretmenlerine ve Sosyal Bilgiler alanına ilgisi olan tüm bireylere drama yöntemin tanıtılması ve yöntemin diğer ünite ve konulara uygulanması açısından faydalı olacăg 1 düşünülmektedir. Bununla birlikte bu araştırma sonucunda elde edilecek olan bulguların konu ile ilgili yapılmış olan diğer çalışmalara katkı sunacağı ve kaynak olacağ 1 düşünülmektedir.

Araştırmanın temel amacı 5. sınıf Sosyal Bilgiler dersinde drama yönteminin kullanılmasına ilişkin öğrenci görüşlerini belirlemektir. Bu amaç doğrultusunda aşağıda verilen sorulara cevap aranmıştır:

a. Öğrencilerin, drama yönteminde uygulamalar sırasında sevilen etkinliklere yönelik görüşleri nelerdir?

b. Öğrencilerin, drama yönteminde uygulamaların faydalı yönleri hakkında görüşleri nelerdir?

c. Öğrencilerin, drama yönteminde uygulamalar sirasında problem yaşadıkları durumlar nelerdir?

d. Öğrencilerin, drama yönteminde uygulamaları daha etkili bir duruma getirmek için önerileri nelerdir?

\section{YÖNTEM}

\section{Araştırmanın Modeli}

Araştırma, nitel araştırma yöntemine uygun olan eylem araştırması ile yürütülmüştür. Eylem araştırması, uygulamanın içinde olan bir uygulayıcının kendisinin veya bir araştırmacı ile beraber gerçekleştirdiği ve uygulama sürecine ilişkin sorunların ortaya çıkarılması ya da hâlihazırda var olan bir sorunu anlama ve çözmeye yönelik sistematik veri toplamayı ve analiz etmeyi kapsayan bir araştırma yaklaşımıdır (Yıldırım ve Şimşek, 2016: 307). 


\section{Çalışma Grubu}

Araştırmanın çalışma grubunu 2013-2014 eğitim öğretim yılı güz dönemi Elazı̆̆ il merkezinde 5. sinıfta öğrenim gören 17'si kız, 21'i erkek toplam 38 öğrenci oluşturmaktadır. Çalışma grubu amaçsal örnekleme yöntemlerinden biri olan kolay ulaşılabilir durum örneklemesi ile belirlenmiştir. Kolay ulaşılabilir durum örneklemesi araştırmaya hız ve pratik kazandıran bir yöntemdir. $\mathrm{Bu}$ yöntemde araştırmacı, kendisine yakın olan ve erişilmesi kolay olan bir durumu seçer (Yıldırım ve Şimşek, 2016: 123).

\section{Veri Toplama Aracı}

Araştırmada veriler görüşme yöntemi kullanılarak elde edilmiştir. "Görüşme, en az iki kişi arasında sözlü olarak sürdürülen bir iletişim sürecidir. Görüşme belirli bir araştırma konusu veya bir soru hakkında derinlemesine bilgi sağlar" (Büyüköztürk, Kılıç Çakmak, Akgün, Karadeniz ve Demirel, 2013: 161). Görüşmeler uygulama sürecine dönük olarak öğrenciler ile yapılarak verilerin zenginleştirilmesi ve çeşitlendirilmesi sağlamıştır.

Araştırmada yarı yapılandırılmış görüşme formu kullanılmıştır. "Yarı yapılandırılmış görüşmeler, görüşme esnasında keşfedilecek soru ve konu listesinden oluşur. Araştırmacıya zaman esnekliği sağlar ve ayrıca belirli bir forma dayalı görüşme, farklı bireylerden daha sistematik ve karşılaştırılabilir bilgi elde etmeyi de sağlar” (Avc1, 2008: 160).

Görüşme formunda yer alan soruları hazırlamak için öncelikle literatür taramas1 yapılmıştır. Daha sonra hazırlanan taslak görüşme formu Firat Üniversitesi Eğitim Fakültesi Türkçe ve Sosyal Bilimler Eğitimi Bölümü Sosyal Bilgiler Eğitimi Ana Bilim Dalı'ndan üç öğretim üyesinin görüşleri alınarak görüşme formu hazır hale getirilmiştir. Sosyal Bilgiler dersinde drama yönteminin kullanılmasına ilişkin öğrencilerin görüsslerini, düşüncelerini ve önerilerini tespit etmek amacıyla araştırmacı tarafından geliştirilen öğrencilere yönelik 4 sorudan oluşan görüşme formu veri toplama aracı olarak kullanılmıştır.

\section{Veri Toplama Süreci}

Araştırma 2013-2014 eğitim öğretim yılında Elazı ̆̆ il merkezinde 5. sınıfta öğrenim gören 38 öğrenci ile uygulanmıştır. Sosyal Bilgiler dersinin "Bölgemizi Tanıyalım" ünitesinde gerçekleştirilen drama yönteminin kullanımına yönelik uygulamalar 02.12.2013 tarihinde başlayıp, 17.02.2014 tarihinde sona ermiştir.

Öğrencilere öncelikle drama yönteminin uygulanmasına yönelik belirlenmiş etkinlikler anlatılmıştır. Bu etkinliklere göre öğrenciler belirtilen sayıda olmak şartıyla 9-10 kişilik gruplar oluşturmuş, her gruptan bir lider seçilmiş ve 


\section{F.Ezer-S.Aksüt $\quad$ 5. Sınıf Sosyal Bilgiler Dersinde Drama Yönteminin...}

öğrencilerin istedikleri görevleri seçmeleri istenmiştir. Öğrencilerin seçtikleri görevleri yerine getirirken hakkında çok fazla bilgi sahibi olmadıkları etkinlikler araştırmacı tarafından açıklanmıştır. "Bölgemizi Tanıyalım” ünitesinin doğal afet konusuyla ilgili öğrenciler drama metni hazırlamıştır. Araştırmacının bu süreçteki rolü, drama metinlerinin hazırlaması sürecinde malzemelerin dağıtılmasına, toplanmasına yardım etmek ve sürece ilişkin gözlem yapmaktır. Metinler hazırlandıktan sonra öğrenciler ile etkinlikler prova edilmiş ve daha sonra bu etkinlikler sınıfta canlandırılmıştır. Drama etkinliklerinde güven ve uyum gibi özellikleri öğrenciye kazandıran ısınma çalışması, kendilerine verilen bir role yorumlarını katarak oynama aşaması, öğrencilerin hem fiziksel hem de zihinsel olarak rahat hareket edebilmesi için rahatlama aşaması, hem kendini hem de diğer gruptakileri değerlendiren değerlendirme aşaması çeşitli etkinliklerle öğrencilere uygulanmıştır.

Sınıflarda yürütülen uygulamaların ardından uygulama sonrası çalışmaların tamamlanmasına aşamasına geçilmiştir ve uygulanan yöntem ile ilgili öğrenci görüşlerini tespit etmek için öğrenciler ile görüşmeler yapılmıştır. Öncelikle çalışma grubuna görüşmeye başlamadan araştırmada yer alan sorular ile ilgili kısa bilgiler verilmiştir. Yapılan görüşmeler yüz yüze yapılmış ve bu görüşmeler 1015 dakika sürmüştür. Görüşme sürecinde güvenilirliği ve objektifliği sağlamak adına öğrencilerin görüşleri, izin alınarak ses kayıt cihazı aracıyla kayıt altına alınmıştır.

\section{Verilerin Analizi}

Araştırmada elde edilen verilerin çözümlenmesinde içerik analizi yöntemi kullanılmıştır. İçerik analizi, "Sözel, yazılı ve diğer materyallerin içerdiği mesajı, anlam ve veya dilbilgisi açısından nesnel ve sistematik olarak sınıflandırma, sayılara dönüştürme ve çıkarımda bulunma yoluyla sosyal gerçeği araştıran bilimsel bir yaklaşımdır" (Tavşancıl ve Aslan, 2001: 22).

Araştırma verilerinin (görüşmeler) değerlendirilmesinde nitel veri analiz programından yararlanılmıştır. Görüşmelerden elde edilen veriler hiçbir değişiklik yapılmadan bilgisayar ortamına aktarılarak analize uygun bir hale getirilmiştir. Görüşmedeki ifadelerin analizini kolaylaştırmak için araştırmanın amacına uygun olacak şekilde bu ifadeler kısa ve anlamlı semboller halinde kodlanmıştır. Daha sonra ilgili literatür ile ilişki sağlanarak kategoriler oluşturulmuştur. Kod ve kategori listesi oluşturularak bu liste kendi içerisinde tutarlı olacak şekilde veriler organize edilmiştir. Kategoriler arasındaki ilişki belirlenerek ana kategori ve alt kategoriler araştırma sorularının altına toplanmıştır. Böylece kaç katılımcının aynı kategoriye vurgu yaptığı ortaya konulmuştur. Elde edilen kategoriler ve yükleme sayıları daha net ve kapsamlı bir görüntünün sağlanması için modeller halinde sunulmuştur. Katılımcı 
görüşlerinden doğrudan alıntılara yer verilerek modeller yorumlanmıştır. $\mathrm{Bu}$ modellerde sunulan kategorilere ve alt kategorilere yönelik katılımcı görüşleri, tırnak içerisinde italik olarak verilmiştir. Ayrıca katılımcılara ilişkin kişisel bilgiler, katılımcı görüşlerinin başında (Ö.1.K/E), (Öğrenci, 1. kişi, Kız/Erkek) şekilde kısaltmaların yer aldığ 1 kodlamalar ile verilmiştir.

Araştırma sonucunda verilerin ayrıntılı bir şekilde rapor edilmesi ve araştırmacıların sonuçlara nasıl ulaştığını detaylıca açılaması nitel araştırmalarda geçerliğin sağlanması açısından önemli görülen ölçütlerdir (Yıldırım ve Şimşek, 2016: 270). Bu sebeple araştırmada geçerliğin sağlanması amacıyla araştırma sonuçlarına nasıl ulaşıldığı detaylı bir şekilde açıklanmış ve araştırmada elde edilen veriler bulgular kısmında ayrıntılı şekilde rapor edilmiştir.

Araştırmanın güvenirliğini sağlamak için araştırma verileri uzman ve araştırmacı tarafından birbirinden bağımsız şekilde değerlendirilerek kodlamalar yapılmış ve daha sonra bu kodlamalar karşılaştııılarak uzman ve araştırmacı arası uyumun olup olmadığını belirlemek için görüş birliği ve görüş ayrılığı sayıları tespit edilerek araştırmanın güvenirliği Miles ve Huberman'ın (1994/2016: 64) güvenirlik formülü "güvenirlik = görüş birliği sayıs / toplam görüş birliği + görüş ayrılığ1 sayısı" kullanılarak hesaplanmıştır. Araştırmada uzman ve araştırmacı arasındaki uyum \% 92.50 olduğu için istenilen düzeyde güvenilirliğin sağlandığ1 belirlenmiştir. Nitel araştırmalarda, uzman ve araştırmacı değerlendirmeleri sonucunda aradaki uyumun \% 90 ve üzeri olduğu durumlarda istenilen düzeyde güvenilirlik sağlanmış olmaktadır (Saban, 2009: 288).

\section{BULGULAR VE YORUM}

5. sınıf Sosyal Bilgiler dersinde drama yönteminin kullanılmasına ilişkin öğrenci görüşleri ile ilgili dört ana kategori belirlenmiştir. Bu kategoriye ilişkin model şekil 1'de verilmiştir. 


\section{F.Ezer-S.Aksüt $\quad$ 5. Sınıf Sosyal Bilgiler Dersinde Drama Yönteminin...}

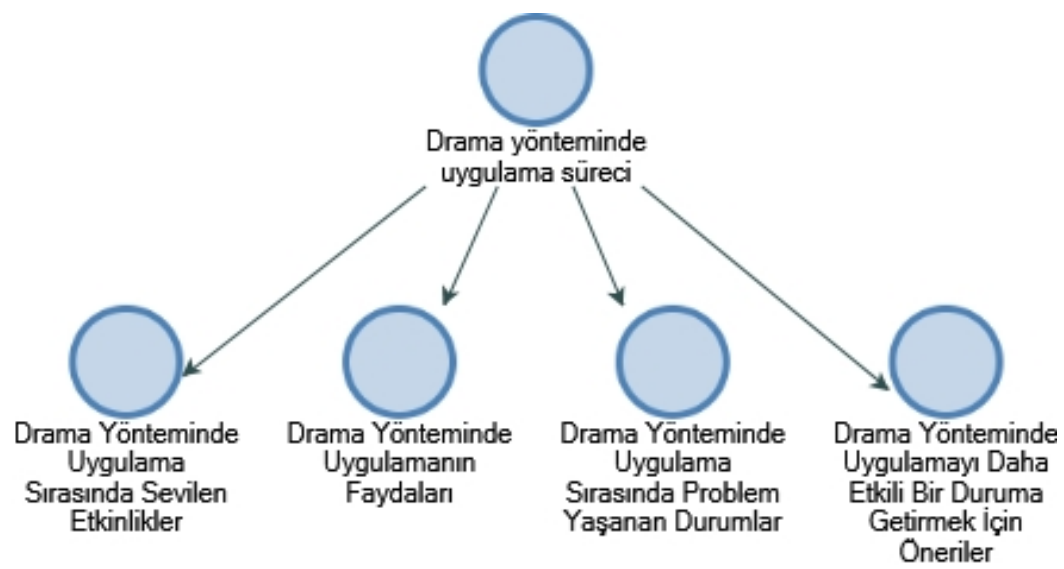

Şekil 1. Drama yönteminde uygulama sürecine ilişkin model

Drama yönteminde uygulama sürecine ilişkin ana kategoriler; "drama yönteminde uygulama sirasinda sevilen etkinlikler”, “drama yönteminde uygulamanın faydaları", "drama yönteminde uygulama sırasında problem yaşanan durumlar" ve "drama yönteminde uygulamayı daha etkili bir duruma getirmek için öneriler” olarak belirlenmiş ve modeller halinde sunulmuştur.

\section{Drama Yönteminde Uygulama Sırasında Sevilen Etkinliklere İlişkin Bulgular}

Öğrencilerin drama yönteminde uygulamalar sırasında sevilen etkinliklere yönelik görüşleri alınmış ve bu görüşler doğrultusunda kategorinin sekiz alt kategorisi olduğu belirlenmiştir. Bu kategoriye ilişkin model ve yükleme sayısı şekil 2'de verilmiştir. 


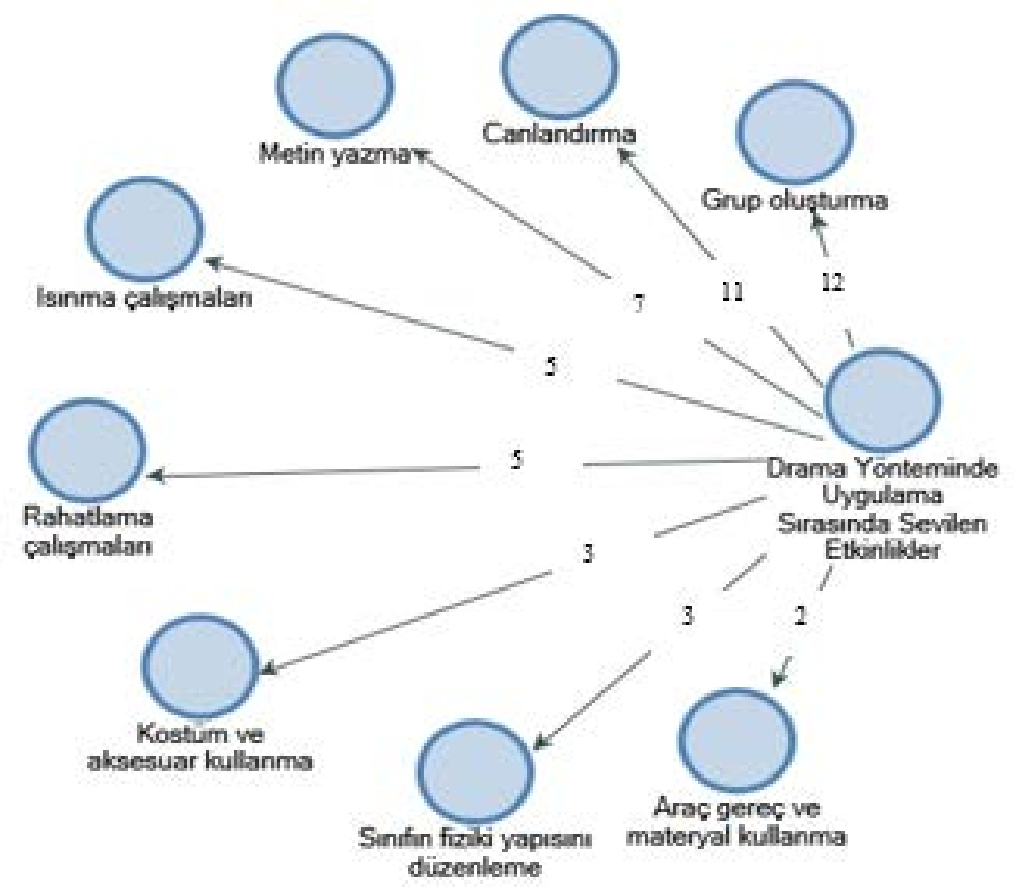

Şekil 2. Drama yönteminde uygulama sırasında sevilen etkinliklere ilişkin model

Drama yönteminde uygulamalar sırasında sevilen etkinliklere ilişkin öğrenci görüşleri değerlendirildiğinde; en fazla yüklemenin "grup oluşturma " alt kategorisine yapıldığ 1 görülmektedir. Drama yönteminde uygulamalar sırasında sevilen etkinliklere ilişkin belirlenen diğer alt kategoriler ise sırasıyla; "canlandırma", "metin yazma", "1sınma çalışmaları" ve "rahatlama çalışmaları", "kostüm ve aksesuar kullanma" ve "sınıfın fiziki yapısını düzenleme" ve "araç gereç ve materyal kullanma" olarak belirlenmiştir. Bazı alt kategorilere ve katılımc1 görüşlerine aşağıda yer verilmiştir.

Drama yönteminde uygulama sırasında sevilen etkinlikler kategorisini "grup oluşturma" alt kategorisi ile ilişkilendiren katılımcı düşüncesini (Ö.32.K.) "Grup kurup arkadaşlarımla beraber çalışmayı sevdim onlarla birçok şey yaptık. Arkadaşlarımla vakit geçirmek çok güzeldi.” cümlesiyle ifade etmiştir. Başka bir katılımc1 düşüncesini (Ö.35.E.) "Genelde derste arkadaşlarımızla beraber bir şeyler yapamıyoruz bu çalışmalar çok iyi oldu beraber grup kurduk ve çok eğlendik." şeklinde açıklarken cümlesiyle aslında öğrencilerin Sosyal Bilgiler dersinde uygulanan bu yöntem ve tekniklerin arkadaşlık ilişkilerini geliştirmesi yönünde faydalı olduğunu ifade ettikleri görülmektedir. 


\section{F.Ezer-S.Aksüt $\quad$ 5. Sınıf Sosyal Bilgiler Dersinde Drama Yönteminin...}

Drama yönteminde uygulama sırasında sevilen etkinlikleri "canlandırma" alt kategorisi ile açıklayan katılımcı (Ö.8.E.) "Drama oynamayı sevdim çünkü çok eğlendim." şeklinde görüşünü belirtirken, diğer bir katılımc1 ise (Ö.17. E.) "Drama canlandırmak çok güzel oldu bence çünkü ben çok eğlendim." şeklinde düşüncesini ifade etmiştir.

"Metin yazma" alt kategorisi ile ilgili görüşünü ifade eden katılımc1 (Ö.15.K.) "Drama etkinliği yazmayl sevdim ve yazdı̆̆ım bu metninde rol almayl sevdim." şeklinde açılama yaparken, başka bir katılımcı ise düşüncesini (Ö.27.K.) "Drama metni yazıp canlandirmak çok güzel oldu bence. Drama yapmayı seviyorum. Bunları yapmak yaratıcllı̆̆ımın gelişmesini sağladı.” Cümlesiyle açıklamıştır.

Katılımcılardan bazıları drama yönteminde uygulama sırasında sevilen etkinlikleri "isınma çalışmaları" alt kategorisiyle ilişkilendirmişlerdir. Katılımcılardan biri düşüncesini (Ö.2.E.) "Uygulama sırasında ısinma ve rahatlama hareketlerini çok sevdim ve çok eğlendim." cümlesiyle dile getirmiştir.

Katılımcılardan biri, drama yönteminde sevilen etkinlikleri "kostüm ve aksesuar kullanma" alt kategorisi ile ilişkilendirerek düşüncesini (Ö.5.E.) "Drama esnasinda sinifta etkinliğime uygun klyafet giydim ve oyuncak mikrofon kullandım." cümlesiyle dile getirmektedir.

\section{Drama Yönteminde Uygulamanın Faydalarına İlişkin Bulgular}

Drama yönteminde uygulamaların faydalarına ilişkin öğrenci görüşleri alınmış ve bu görüşler değerlendirildiğinde kategorinin on iki alt kategorisi olduğu belirlenmiştir. Bu kategoriye ilişkin model ve yükleme sayısı şekil 3'de verilmiştir. 


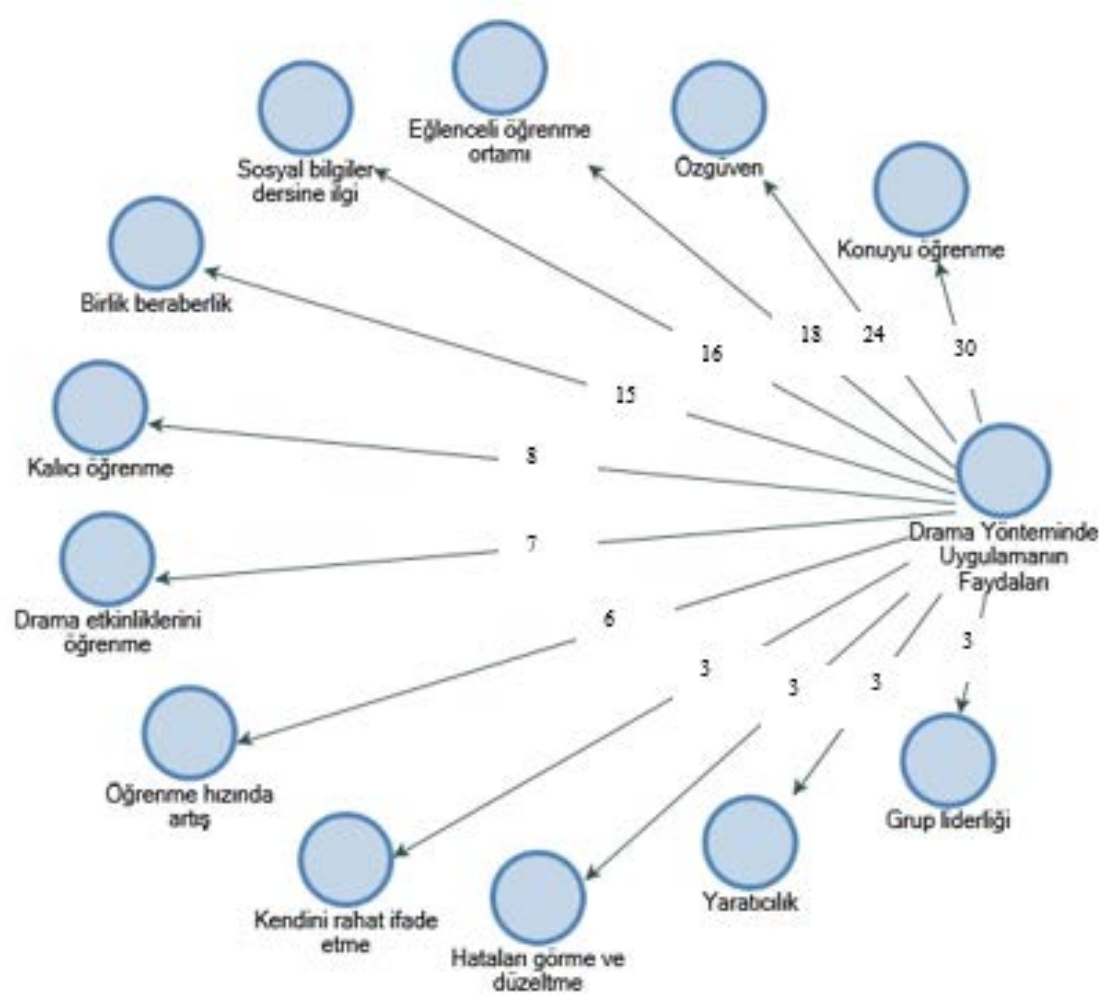

Şekil 3. Drama yönteminde uygulamanın faydalarına ilişkin model

Drama yönteminde uygulamaların faydalarına ilişkin öğrenci görüşlerinden elde edilen veriler incelendiğinde; en fazla yüklemenin "konuyu öğrenme" alt kategorisine yapıldığ 1 belirlenmiştir. Drama yönteminde uygulamaların faydalarına ilişkin belirlenen diğer alt kategoriler ise "özgüven", "eğlenceli öğrenme ortamı", "Sosyal Bilgiler dersine ilgi", "birlik beraberlik", "kalıcı öğrenme", "drama etkinliklerini öğrenme", "öğrenme hızında artış", "kendini rahat ifade etme", "hataları görme ve düzeltme", "yaratıcılık" ve "grup liderliğii" şeklinde sıralandığı görülmektedir. Bazı alt kategorilere ve katılımcı görüşlerine aşağıda yer verilmiştir.

Drama yönteminde uygulamaların faydaları kategorisini "konuyu öğrenme" alt kategorisi ile ilişkilendiren katılımcı (Ö.10.E.) "Doğal afet konusunu çok iyi ögrendim. Testlerle sevdiğim konuyu daha iyi anladım. Sinavda kolayllk sağlayacă̆ından eminim.” cümlesiyle düşüncesini açıklarken, diğer bir katılımcı (Ö.14.E.) "Evet tüm etkinliklerin bana faydaları oldu. Yaptığımız etkinliği çok sevdim. Çünkü benim derslerime çok yardımcı oldu. Çünkü konuları pekiştirdim. Doğal afet konusunu ögrendim." cümlesiyle uygulamaların bilgileri 


\section{F.Ezer-S.Aksüt $\quad$ 5. Sınıf Sosyal Bilgiler Dersinde Drama Yönteminin...}

pekiştirdiğini ifade etmiştir. Başka bir katılımcı (Ö.17.E.) "Hem eğitici hem de ögretici yönde etkilediği için sevdim. Yaptı̆̆ımız ve oynadı̆̆ımız etkinlikler hem eğlenmemizi hem de öğrenmemizi sağladl. Etkinlikte hiç bilmediğim bilgileri ögrrendim. Konиyu daha iyi anladım." cümlesiyle düşüncesini özetlemiştir. Başka bir katılımcı (Ö.19.E.) "Hem ögretici hem de derslerimize yararlı olduğu için sevdim. Konuyu daha iyi anladım. Gerçek hayatta ne yapmam gerektiğini ögrrendim." cümlesiyle daha kolay öğrenme boyutunu vurgulamıştır. Başka bir katılımc1 düşüncesini (Ö.27.K.) "Normal dersimizden öğrendiğimizi fazla anlamadım ama yaptı̆̆ımı etkinlik beni çok geliştirdi. Doğal afet konusunda bilgim arttı. Sosyal bilgiler dersini bu konulart daha iyi öğrenmemi sağladl." şeklinde ifade ederken, diğer bir katılımcı (Ö.28.E.) "Doğal afet konusunu daha iyi anladım. Çözdü̆̈̈̈müz testlerde bilmediğimiz bilgileri ögrendim. Bu bilgiler ileride bizim işimize çok yarayabilir. Ileride bir afet olduğunda neler yapacă̆ımızı ögrendik. Biz de ileride çevremizdekilere anlatıp onlar bilgilendirebiliriz.” biçiminde düşüncesini ifade etmiştir. Drama yönteminin konuyu öğrenme boyutuna dikkat çeken öğrenciler yapılan etkinlikler sonrasında konuları daha kolay öğrendikleri ve bu durumun özel hayatlarını da etkilediklerini ifade ettikleri görülmektedir.

Drama yönteminde uygulamaların faydalarını "özgüven" alt kategorisi ile açılayan katılımcı (Ö.2.E.) "Özgüven kazandırdl. Görüşlerimi rahatlıkla söyledim neler yaptığımı gördü̈m” şeklinde görüşünü belirtirken, benzer şekilde düşünen başka bir katılımc1 (Ö.3.K.) "Kendime güvenim geldi. Böyle çalışmalarda neler yapabileceğimin farkına vardım. Konuyla ilgili bildiklerimi rahatlıkla söyledim." şeklinde düşüncesini ifade etmiştir. Bir başka katılımcı (Ö.11.K.) "Bireysel konuşmalar sayesinde duygularımın ortaya çıkmasını sağladt. Kendime güvenim geldi." şeklinde düşüncesini açılkarken, diğer bir katılımc1 (Ö.15.K.) "Kendimi tanıdım drama da neler yapabileceğimi gördüm. $B u$ çalışmalar ile isteyince neler yapabileceğimi gördüm.” Cümlesiyle düşüncesini belirtmiştir. Benzer şekilde düşünen bir katılımcı (Ö.16.K.) "Drama da neler yapabileceğimi gördüm. Bildiklerimi rahatlıkla söyledim. Özgüvenim arttı." cümlesiyle düşüncesini açıklarken, diğer bir katılımc1 da (Ö.21.E.) "Kendime özgüvenim geldi. Eskiden sahneye fazla çıkıp kameraya çekilmekten korkardım ama şimdi korkmuyorum." şeklinde görüşünü belirtmiştir.

"Eğlenceli öğrenme ortamı" alt kategorisi ile ilgili görüşünü açıklayan katılımc1 (Ö.22.K.) "Hem eğlenceliydi hem de konuyu kendimiz yaptığımız için çok sevdim. Drama etkinliğinde çalışırken çok ĕglendim. Drama etkinliği eğlenerek yaptık." cümlesiyle düşüncesini belirtirken, ayn1 şekilde düşünen başka bir katılımcı (Ö.24.E.) "Hem ögretici hem de eğlendiriciydi. Yaptığımız oyunlar eğlenceliydi.” şeklinde açıklama yapmıştır. Benzer şekilde düşünen katılımc1 (Ö.34.E.) "Yaptı̆̆ımız ve oynadı̆ğmız etkinlikler hem ĕglenmemizi hem 
de öğrenmemizi să̆ladı. Drama etkinliği çok eğlenceliydi." şeklinde açıklama yapmiştır.

Katılımcılardan bazıları drama yönteminde uygulamaların faydalarını "Sosyal Bilgiler dersine ilgi" alt kategorisiyle ilişkilendirmişlerdir. Uygulamada yapılan etkinliklerin kendileri için faydalı olduğunu düşünen katılımcı (Ö.13.K.) "Sosyal Bilgiler dersini seviyordum daha da ilgim arttı. Sosyal dersi için daha çok bilgi edinmemi sağladı. Ĕgitim hayatında derslerime katkısı oldu." şeklinde düşüncesini ifade ederken, başka bir katılımc1 (Ö.17.E.) "Hem eğitici hem de ögretici yönde etkiledi. Sosyal Bilgiler dersine ilgim arttı. Sosyal Bilgiler dersini bu konuları daha iyi öğrenmemi sağladı." şeklinde düşüncesini ifade etmiştir. Başka bir katılımcı ise (Ö.37.K.) "Sosyal Bilgiler dersine ilgim arttı daha neler yapacağız diye bekledim." şeklinde düşüncesini özetlemeye çalışmıştır.

Katılımcılardan biri, drama yönteminde uygulamaların faydalarını "birlik beraberlik" alt kategorisi ile ilişkilendirerek düşüncesini (Ö.1.E.) "Bazı arkadaşlarımı hiç tanımıyordum bu etkinlikler sayesinde arkadaşlarımın özelliklerini tanıdım. Güvenim arttı. Grubumuzla uyum içinde çalışmamı sağladı." cümlesiyle özetlemeye çalışırken, bir diğer katılımcı (Ö.7.E.) "Arkadaşlarımla birlikte drama yapmayı sevdim. Arkadaşlarımla ilişkilerim güçlendi. Birbirimize olan güvenimizi arttırdı. Bazı arkadaşlarımın çok eğlenceli olduğunu gördüm. Drama bana grup içinde çalısmayı ögretti." temayla ilgili olarak cümlesini dile getirmiştir. Benzer şekilde düşünen katılımc1 (Ö.29.K.) "Arkadaşlarıma daha çok güvenmemi sağladı. Gruplarda samimi arkadaşlarım oldu. Etkinlikler sınıfta beraberliğimizi artırdl." şeklinde düşüncesini ifade ederken, bir diğer katılımc1 (Ö.32.K.) "Grubumdaki kişiler iyi anlaşstı̆̆ım kişiler olduğu için çok sevdim. Hem de arkadaşlarımızla çalışırken birlik ve beraberlik içinde daha çok vakit geçirmek hoşuma gitti. " cümlesiyle görüşünü belirtmiştir. Birlik beraberlik alt kategorisini belirten öğrencilerin Sosyal Bilgiler dersinde uygulanan bu yöntem ve tekniklerin arkadaşlık ilişkilerini geliştirmesi açısından faydalı olduğunu düşündükleri görülmektedir.

\section{Drama Yönteminde Uygulama Sırasında Problem Yaşanan Durumlara İlişkin Bulgular}

Drama yönteminde uygulama sırasında problem yaşanan durumlara ilişkin öğrencilerin görüşleri alınmış ve bu görüşlerden elde edilen veriler doğrultusunda, bu kategori ile ilgili dokuz alt kategori olduğu belirlenmiştir. $\mathrm{Bu}$ kategoriye ilişkin model ve yükleme sayısı şekil 4'de verilmiştir. 


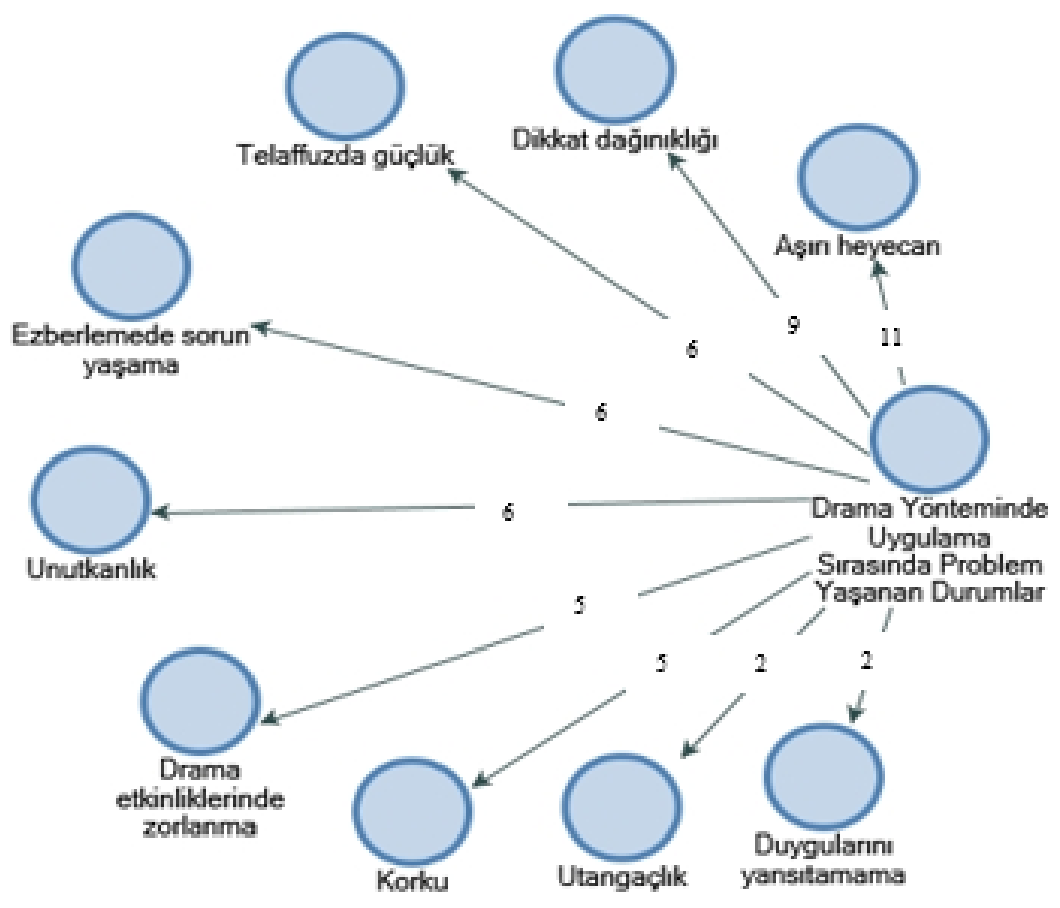

Şekil 4. Drama yönteminde uygulama sırasında problem yaşanan durumlara ilișkin model

Drama yönteminde uygulama sırasında problem yaşanan durumlara ilişkin veriler değerlendirildiğinde; en fazla yüklemenin "aşırı heyecan” alt kategorisine yapıldığı görülmektedir. Belirlenen diğer alt kategoriler ise sırayla; "dikkat dağınıklığı", "telaffuzda güçlük”, "ezberlemede sorun yaşama", "unutkanlık", "drama etkinliklerinde zorlanma”, "korku”, "utangaçlık", "duygularını yansıtamama" olarak belirlenmiştir. Bazı alt kategorilere ve katılımcı görüşlerine aşağıda yer verilmiştir.

Drama yönteminde uygulama sırasında problemler yaşanan durumlar kategorisini "aşırı heyecan" alt kategorisi ile ilişkilendiren katılımcı (Ö.2.E.) "Senaryoyu ezberledim fakat oyun sirasinda heyecandan bazı yerlerde duraksadım." cümlesiyle düşüncesini ifade etmiştir. Başka bir katılımcı düşüncesini (Ö.6.K.) "Drama etkinliğinde heyecanlandım ve yapamayacağımı düşündüm böyle düşündügüm içinde daha çok heyecanlandım." cümlesiyle özetlerken, diğer bir katılımcı (Ö.15.K.) "Drama esnasında heyecanlandığım için gözlerimi kapattım neden bu kadar heyecanlandığımı anlamadım." şeklinde fikrini ifade etmiştir. 
"Telaffuzda güçlük" alt kategorisini açıklayan katılımcı (Ö.10.E.) "Kelimeleri söylerken takıldım. Drama canlandırdiğımda durakladım ve sesimi duyuramadım." şeklinde görüşünü belirtirken, başka bir katılımcı (Ö.13.K.) "Etkinlikte bir hata yaptım bu yüzden bir kelimeyi çok kekeledim." cümlesiyle düşüncesini açıklamıştır. Benzer şekilde düşünen katılımcı (Ö.14.E.) "Etkinlikte biraz yanlış sözcükler söyledim bence çok heyecan yaptım." Cümlesiyle düşüncesini özetlemiştir.

"Dikkat dağınıklığı" alt kategorisi ile ilgili düşüncesini ifade eden katılımcı (Ö.3.K.) "Evet güçlük çektim arkadaşlarım ses çıkardıklart için dikkatim dağıldd. Kelimeleri unuttuğum için etkinliğe istediğim gibi odaklanamadım." şeklinde açıklama yapmıştır. Başka katılımcı (Ö.18.K.) "Arkadaşlarım ses çıkardıkları için çok sesli konuşmak zorunda kaldım bunun için dikkatim çok dağıldı." cümlesiyle görüşünü belirtirken, başka bir katılımcı (Ö.20.E.) “Benim grubumdaki arkadaşlarım drama etkinliğini güzel yapamadıkları için dikkatim dağıldl. Rolümün bazı yerlerinde yoğunlaşamadım." cümlesiyle düşüncesini özetlemeye çalışmıştır.

Drama Yönteminde Uygulamayı Daha Etkili Bir Duruma Getirmek İçin Önerilere İlişkin Bulgular

Öğrencilerinin drama yönteminde uygulama sırasında problem yaşadıkları belirlenmiştir. $\mathrm{Bu}$ doğrultuda drama yönteminde uygulamaları daha etkili bir duruma getirmek için önerilere ilişkin görüşleri alınmıştır. Bu görüşlerden elde edilen veriler doğrultusunda, drama yönteminde uygulamaları daha etkili bir duruma getirmek için öneriler ile ilgili sekiz alt kategori olduğu belirlenmiştir. Bu kategoriye ilişkin model ve yükleme sayısı şekil 5'de verilmiştir. 
F.Ezer-S.Aksüt $\quad$ 5. Sınıf Sosyal Bilgiler Dersinde Drama Yönteminin...

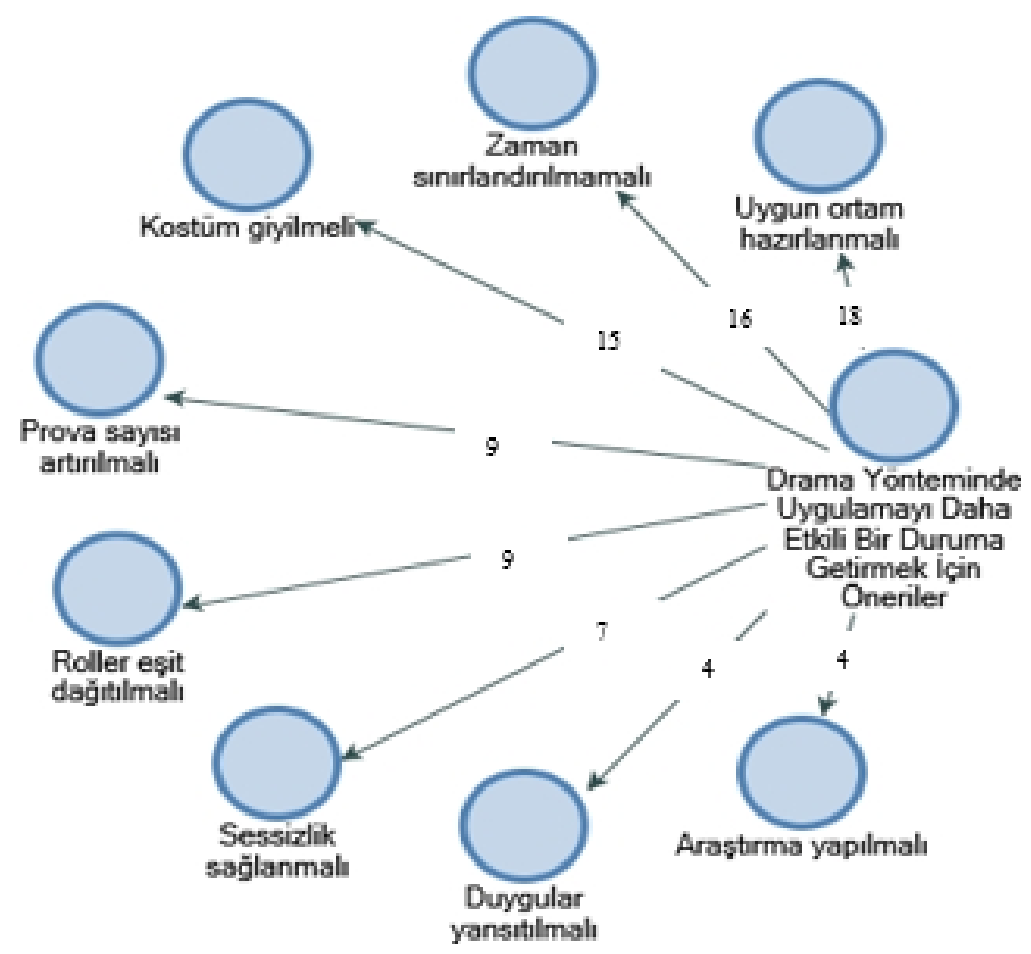

Şekil 5. Drama yönteminde uygulamayı daha etkili bir duruma getirmek için önerilere ilişkin model

Drama yönteminde uygulama sırasında bazı problemler yaşandığ 1 ve yaşanan bu problemlerin çözümüne yönelik öğrencilerin bazı önerilerinin olduğu belirlenmiştir. Drama yönteminde uygulamayı daha etkili bir duruma getirmek için önerilere ilişkin model incelendiğinde; en fazla yüklemenin "uygun ortam hazırlanmalı" alt kategorisine yapıldığı belirlenmiştir. Belirlenen diğer alt kategoriler ise "zaman sinırlandırılmamalı", "kostüm giyilmeli", "prova sayıs1 artırılmalı", "roller eşit dağıtılmalı”, "sessizlik sağlanmalı”, “duygular yansıtılmalı", "araştırma yapılmalı" şeklinde sıralandığı görülmektedir. Bazı alt kategorilere ve katılımcı görüşlerine aşağıda yer verilmiştir.

Drama yönteminde uygulamayı daha etkili bir duruma getirmek için öneriler kategorisini "uygun ortam hazırlanmalı" alt kategorisi ile ilişkilendiren katılımc1 (Ö.5.E.) "Ortam olarak sinuf değil de başka bir yer olsaydı daha etkili olurdu. Sinıfi metne uygun ortama dönüştürseydik daha rahat oynayabilirdik." cümlesiyle düşüncesini ifade ederken, bir diğer katılımcı (Ö.22.K.) "Etkinliği sinuf yerine başka yerde yapsak daha mı iyi olurdu. Drama etkinliğinde oyun sahneleri yapabilirdik.” şeklinde düşüncesini ifade etmiştir. Kategori ile ilgili 
benzer şekilde düşünen katılımcı (Ö.38.E.) "Sinıfımız oyun için küçüktü başka yerde yapsak iyi olurdu. Alanımı daha büyük olsaydı daha rahat hareket edebilirdik.” şeklinde düşüncesini açılamıştır.

“Zaman sınırlandırılmamalı” alt kategorisi ile ilgili katılımcı (Ö.9.K.) “Daha fazla vaktimiz olsaydı belki başka etkinliklerde yapardık. Bence okul dışında daha çok zaman vermeliydik. O zaman daha iyi olurdu." cümlesiyle süreçte yaşanan bir problemin çözümüne yönelik bir öneriye dikkat çekmiştir. Yine katılımcılardan biri düşüncesini (Ö.14.E.) "Zamanımız daha çok olsaydı daha iyi çalışabilirdik. Ders saatleri dışında daha çok zaman ayırabilirdik." şeklinde ifade ederken, başka bir katılımc1 (Ö.23.K.) "Benim ve grup arkadaşlarımın bazı yerlerde hataları oldu daha uzun süre çalışabilirdik. Zamanı iyi kullanmalıyız." cümlesiyle açıklama yapmıştır. Öğrenciler, bu etkinliklerin daha başarılı olması için zamanın sınırlandırılmaması gerektiği yönünde görüş belirtmişlerdir.

"Kostüm giyilmeli” alt kategorisi ile ilgili görüşünü belirten katılımcı (Ö.8.E.) "Kostüm giyseydik daha iyi olurdu ben öyle rolüme daha iyi motive olurdum." cümlesiyle düşüncesini ifade ederken, başka bir katılımcı (Ö.18.K.) "Forma yerine drama ya uygun başka elbiseler giyseydik daha mi iyi olurdu ama bizim o kadar zamanımız yoktu. " cümlesiyle süreçte yaşanan bir probleme yönelik çözüm önerisine dikkat çekmiştir. Benzer şekilde düşünen katılımc1 düşüncesini (Ö.28.E.) “ Drama etkinliğinde okul formalarımızı değil de ona uygun klyafetler giyebilirdik. Kendi rolümün elbisesini giymek isterdim.” şeklinde ifade etmiştir. Ögrencilerin etkinliklerde kostüm giymemelerinin etkinliğe motive olmalarına engel olduğu ve bundan dolayı kostüm giyilmesinin gerekli olduğuna yönelik açıklama yaptıkları görülmektedir.

Katılımcılardan bazıları drama yönteminde uygulamayı daha etkili bir duruma getirmek için önerileri "prova sayısı artırılmalı" alt kategorisiyle ilişkilendirmişlerdir. Katılımcılardan biri düşüncesini (Ö.25.E.) "Tüm etkinliklerde biraz daha fazla tekrar yapmamı gerekiyordu. Çünkü drama sirasında biraz zorlandım." biçiminde ifade ederken, başka bir katılımcı düşüncesini (Ö.33.K.) "Daha çok çalışarak bu etkinlikleri daha verimli hale getirebilirdik. Hafta sonu çalışmaları yapsaydık daha etkili olurdu." cümlesiyle dile getirmiştir.

\section{SONUÇ, TARTIŞMA VE ÖNERILER}

5. sınıf Sosyal Bilgiler dersinde drama yönteminin kullanılmasına ilişkin öğrenci görüşleri doğrultusunda elde edilen bulgular incelendiğinde şu sonuçlara ulaşı1mıştır.

Öğrencilerin drama yönteminde uygulama sırasında sevilen etkinlikleri genel "grup oluşturma" şeklinde ifade ettikleri belirlenmiştir. Ayrıca drama 


\section{F.Ezer-S.Aksüt $\quad$ 5. Sınıf Sosyal Bilgiler Dersinde Drama Yönteminin...}

yönteminde uygulama sırasında sevilen etkinlikleri "canlandırma", "metin yazma", "1sınma çalışmaları", "rahatlama çalışmaları", "kostüm ve aksesuar kullanma", "sınıfın fiziki yapısını düzenleme" ve "araç gereç ve materyal kullanma" olarak ifade ettikleri belirlenmiştir. Bu sonuçlar ile öğrencilerin ilgi alanlarına uygun olan etkinleri yapmaktan daha çok hoşlandıkları görülmektedir.

Öğrencilerin, Sosyal Bilgiler öğretiminde drama yönteminin öğrenme üzerindeki faydalarını "konuyu öğrenme", "özgüven", "eğlenceli öğrenme ortamı", "Sosyal Bilgiler dersine ilgi", "birlik beraberlik", "kalıcı öğrenme", "drama etkinliklerini öğrenme", "öğrenme hızında artış", "kendini rahat ifade etme", "hataları görme ve düzeltme", "yaratıcılık" ve "grup liderliği" şeklinde ifade ettikleri belirlenmiştir. Benzer şekilde Akkaya (2012) tarafından yürütülen araştırmada öğrencilerinin dersin drama yöntemiyle işlenmesinin dersi eğlenceli hale getirdiği, kalıcı öğrenme sağladığı, daha iyi anlamalarını sağladığı, grup çalışmasının faydalı olduğu, empati becerilerini geliştirdiği ve iyi bir öğrenme yöntemi olduğu şeklinde ifade ettikleri görülmüştür. Kadan'ın (2013) çalışmasında öğrencilerin yaratıcı drama yöntemi ile işlenen dersleri daha eğlenceli, güzel ve zevkli geçtiği, anlayamadığımız konuları daha iyi anlıyoruz, öğrendiklerimiz kalıcı oldu, ders daha akıcıydı ve ders çok güzel işleniyor gibi ifadede ettikleri sonucuna ulaşılmıştır. Kahriman'ın (2014) çalışmasında öğrencilerden elde edilen verilere göre drama yönteminin dersleri öğrenciler için zevkli hale getirdiği ve öğrencilerin daha aktif olmasını sağladığı belirlenmiştir. Erdem Zengin'in (2014) çalışmasında değerlerin öğretiminde yaratıcı drama yönteminin kullanılması öğrencilerin derse zevkle katılmalarını, eğlenerek ve yaşayarak öğrenmelerini sağladığı sonucuna ulaşılmıştır. Saraç'ın (2015) çalışmasında öğrencilerin günlüklerinde drama etkinlikleri sayesinde konuları daha iyi anladıklarını, eğlenerek öğrendiklerini ve drama çalışmaları sırasında derslerinin daha zevkli geçtiğini ifade ettikleri görülmektedir. Karaosmanoğlu'nun (2015) çalışmasında öğrenciler yaratıcı drama etkinlikleri ile daha iyi öğrendikleri, dersin akıllarında daha iyi kaldığı, dersin daha eğlenceli olduğu, derse motive oldukları, zor olan derslerin daha kolay ve anlaşılır olacağı, öğrencilerin arkadaşlarıyla kaynaştıkları, öğretmenleriyle daha kolay iletişim kurdukları ve kendilerini daha rahat ifade ettikleri yönlerinden faydalı olduğunu ifade ettikleri sonucuna ulaşılmıştır. Pektezel'in (2017) çalışmasında öğretmen drama etkinliklerinin öğrenciyi öğrenmeye karş1 istekli hale getirdiği ve aktifleştirdiği, bu etkinliklerin sinıfta olumlu bir iklim oluşturduğu ve öğrencilerin kendilerini daha iyi ifade etmelerini sağladığı sonucuna ulaşılmıştır. İbiş (2017) tarafindan yapılan çalışmada yaratıcı drama ile kalıcı öğrenmenin sağlandığ 1 ve çocuğun olumlu davranışlar geliştirdiği belirlenmiştir. Çelik ve Buluç (2018) tarafından yapılmış olan çalışmada yaratıcı drama yöntemi ile değer 
eğitimine yönelik öğrencilerin sınıfta eğlenerek öğrendikleri, derste çok mutlu oldukları ve güvenlerinin arttığ 1 sonucuna ulaşılmıştır.

Drama yönteminde uygulama sırasında problem yaşanan durumları öğrencilerin en fazla "aşırı heyecan" ile ifade ettikleri sonucuna ulaşılmıştır. Ayrıca öğrencilerin "dikkat dağınıklığı”, "telaffuzda güçlük”, "ezberlemede sorun yaşama", "unutkanlık", "drama etkinliklerinde zorlanma", "korku", "utangaçlık", "duygularını yansıtamama" gibi farklı problem yaşandıkları belirlenmiştir. Öğrencilerin uygulamalar sırasında problem yaşadıkları durumlar göz önünde bulundurulduğunda genel olarak sosyal duygusal durumlarda problem yaşadıkları görülmektedir. Benzer şekilde Akkaya'nın (2012) çalışmasında öğrencilerin dersin drama yöntemiyle işlenmesi ile derste gürültü, uyumsuzluk, dengesiz rol dağılımı ve yeterli katılımın olmaması gibi bazı problemler yaşandığını ifade ettikleri sonucuna ulaşılmıştır. Kadan (2013) tarafından yapılan çalışmada öğrencilerin açık uçlu anket sorularına verdikleri cevaplar sonucunda yaratıcı drama yöntemine yönelik sınıfta gürültü olduğu, kalabalık sınıf ortamından dolayı anlamada güçlük çekildiği, tiyatro hazırlamanın ve sunmanın zaman aldığ gibi sorunlar ile karşılaşıldığ 1 sonucuna ulaşılmıştır. Koç'un (2013) çalışmasında öğretmenlerin Sosyal Bilgiler dersinde drama yöntemini uygularken öğrencilerde özgüven eksikliği ile karşılaştıkları belirlenmiştir. Pektezel'in (2017) çalışmasında drama etkinliklerinde öğretmenler, sınıfın kalabalık olması ve öğrencilerin ciddiyetsiz hareketleri yüzünden problem yaşandıklarını ifade ettikleri görülmektedir. İşyar'ın (2017) çalışmasında sınıf öğretmenlerinin, sınıfın kalabalık olması ve mekânın drama etkinlikleri için yetersiz olması nedeniyle sorun yaşadıklarını ifade ettikleri belirlenmiştir.

Drama yönteminde uygulamayı daha etkili bir duruma getirmek için önerilere ilişkin öğrencilerin ne fazla "uygun ortam hazırlanmalı" temasını belirttikleri görülmektedir. Öğrencilerin ayrıca; "zaman sınırlandırılmamalı", "kostüm giyilmeli", "prova sayısı artırılmalı”, "roller eşit dağıtılmalı", "sessizlik sağlanmalı", "duygular yansitılmalı" ve "araştırma yapılmalı" gibi önerilerde bulundukları sonucuna ulaşılmıştır. Öğrenciler belirtilen bu önerilerin gerçekleştirilmesi durumunda etkinliklerin daha etkili ve başarılı olabileceğini belirttikleri görülmektedir. Bu sonuca benzer şekilde Koç'un (2013) çalışmasında Sosyal Bilgiler dersinde drama etkinliklerinin yapılabilmesi için uygun mekân ayarlanmalı ve fiziksel şartlar sağlanmalı şeklinde önerilerde bulundukları görülmektedir. Ezer ve Aksüt (2018) tarafından yapılmış olan çalışmada drama yöntemini daha etkili bir hale getirmek için ders saati artırılmalı, uygun çalışma ortamı sağlanmalı, ön hazırlık yapılmalı, kostüm ve aksesuar kullanılmalı şeklinde önerilerde bulundukları görülmüş̧ür.

Araştırma sonuçları doğrultusunda şu önerilere yer verilmiştir. 
F.Ezer-S.Aksüt $\quad$ 5. Sınıf Sosyal Bilgiler Dersinde Drama Yönteminin...

- Öğrenciler arasında derse yönelik olumlu tutumları geliştirmek, öğretim hedeflerine ulaşmak, öğrencinin derse aktif katılımını sağlamak ve yaratıcı bireyler yetiştirmek için öğretmenlerin bu çağdaş öğretim yöntemini kullanması faydalı olabilir.

- Sosyal Bilgiler dersi gibi görsel materyallerin çok kullanıldı̆̆ ve görsellerle zenginleştirilmesi gereken ders ve konularda drama yöntemine sıkça yer verilmelidir.

- Sosyal Bilgiler dersinde drama yönteminin uygulanması sürecinde öğrenciler kendilerini rahat ifade ettikleri, kalıcı öğrenme sağladığ 1 ve eğlenceli öğrenme ortamı sağladığ 1 için farklı derslerde de drama yöntemine yer vermeleri önerilebilir.

- Drama yönteminin sınıf ortamında daha etkili bir şekilde uygulanabilmesi ve zaman kaybının önlenmesi için gerekli altyapının sağlanması ve ihtiyaç duyulan malzemelerin temin edilmesi için gerekli hazırlıklar önceden yapılabilir.

- Drama yönteminin kalabalık olmayan sınıflarda kullanılması daha verimli olabilir. Çünkü sınıf mevcudunun fazla olması öğrencilerin uygulamalar sırasında problem yaşamalarına neden olabilir.

- Drama etkinliklerinin yapılacağı uygun bir ortam olması etkinliklerin amacına ulaşması açısında çok önemlidir. $\mathrm{Bu}$ sebeple okullarda drama etkinliklerinin yapılacağı uygun bir çalışma ortamı oluşturulabilir.

- Drama yönteminin Sosyal Bilgiler dersinde etkili bir şekilde uygulanabilmesi için, öğrencilere çalışmaya başlamadan önce uygulamaların nasıl yürütüleceği konusunda açıklayıcı bilgiler verilebilir.

- Drama yönteminde etkinliklerde görev alan öğrencilerin gönüllü olmalarına dikkat edilmelidir. Fakat içine kapanık öğrencilerin derse aktif katılmayacağ 1 ve kendini sınıftan soyutlayacağı göz önünde bulundurulmalıdır. $\mathrm{Bu}$ yüzden öğrencilerin etkinliklerde aktif olarak yer almalarına dikkat edilmelidir.

- Drama yönteminin daha başarılı olabilmesi için etkinliklere uygun olarak kostüm giyilmeli, gerekli ön araştırmalar yapılmalı, drama yönteminin uygulanacağı ortamda sessizlik sağlamalı, drama uygulamalarından önce daha çok prova yapılmalı ve etkinlik için uygun ortam hazırlanmalıdır. Bu durumlara dikkat edilmesi halinde drama yöntemi daha başarılı hale gelebilir.

- Bu çalışma Sosyal Bilgiler dersine hizmet edecek şekilde uygulanmıştır. Fakat farklı derslere uygulanması açısından sınırlı kalmıştır. Bu nedenle 
yapılacak olan çalışmalar farklı derslerde uygulanabilir ve sonuçlar karşılaştırılabilir.

\section{KAYNAKÇA}

Adıgüzel, Ömer (2014). Eğitimde Yaratıcı Drama (5. baskı). Pegem Akademi, Ankara.

Akkaya, Mavi (2012). Sosyal Bilgilerde Göç Konusunun Drama Yöntemiyle Öğretiminin Akademik Başarıya Etkisi. Yüksek lisans tezi, Gazi Üniversitesi Eğitim Bilimleri Enstitüsü, Ankara.

Aladağ, Elif (2009). Sosyal Bilgiler Eğitiminde Yaratıcı Drama. Mustafa Safran (Ed.), Sosyal Bilgiler Öğretimi içinde (ss. 436-507). Pegem Akademi, Ankara.

Avcı, Muharrem (2008). Bilimsel Araştırmalarda Veri Toplama. Orhan Kılıç ve Mustafa Cinoğlu (Ed.), Bilimsel Araştırma Yöntemleri içinde (ss. 145-170). Lisans Yayıncilik, İstanbul.

Barth, James L. ve Demirtaş, Abdullah (1997). İlköğretim Sosyal Bilgiler Öğretimi. Ankara, YÖK/Dünya Bankası Milli Eğitimi Geliştirme Projesi Yayınları.

Bilgili, Ali Sinan (2006). Geçmişten Günümüze Sosyal Bilimler ve Sosyal Bilgiler. İsmail H. Demircioğlu (Ed.), Sosyal Bilgilerin Temelleri içinde (ss. 3- 56). Hegem Yayınları, Ankara.

Büyüköztürk, Şener; K1lıç Çakmak, Ebru; Akgün, Özcan Erkan; Karadeniz, Şirin ve Demirel, Funda (2013). Bilimsel Araştırma Yöntemleri (15. bask1). Pegem Akademi, Ankara.

Cin, Mustafa (2006). Hayat Bilgisi ve Sosyal Bilgilerde Kullanılabilecek Strateji, Yöntem ve Teknikler. Abdurahman Tanrı̈ğğn (Ed.), Hayat Bilgisi ve Sosyal Bilgiler Öğretimi içinde (ss. 117-162). Arı Maatbaac1lı, İstanbul.

Çağdaş, Aysel; Albayrak, Huriye ve Cantekinler, Semra (2003). Okul Öncesi Eğitimde Dramatik Etkinlikler. Eğitim Kitapevi, Konya.

Çelik, Özkan ve Buluç, Bekir (2018). "Disiplinler Arası Yaklaşımla Değer Öğretiminde Yaratıcı Drama Yönteminin Kullanılması”. Erzincan Üniversitesi Eğitim Fakültesi Dergisi, 20 (1), ss. 67-88. 
F.Ezer-S.Aksüt $\quad$ 5. Sınıf Sosyal Bilgiler Dersinde Drama Yönteminin...

Dirim, Aygören (1998). Okul Öncesi Eğitiminde Yaratıcı Drama. Esin Yayınları, İstanbul.

Doğanay, Ahmet (2005). Sosyal Bilgiler Öğretimi. Cemil Öztürk ve Dursun Dilek (Ed.), Hayat Bilgisi ve Sosyal Bilgiler Öğretimi içinde (ss. 1752). Pegem A Yayınc1lı, Ankara.

Erbay, Filiz (2014). Dramatik Etkinlikler ve Dramada Eğitim Ortamlarının Düzenlenmesi. Esra Ömeroğlu (Ed), Okul Öncesi Eğitimde Dramatik Etkinliklerden Dramaya Teoriden Uygulamaya içinde (ss. 44-51). Eğiten Kitap, Ankara.

Erdem Zengin, Ebru (2014). Yöntem Olarak Yaratıcı Drama Kullanımının İlkokul 4. Sınıf Sosyal Bilgiler Öğretim Programındaki Değerlere Etkisi. Yüksek lisans tezi, Niğde Üniversitesi Eğitim Bilimleri Enstitüsü, Niğde.

Erden, Münire (tarihsiz). Sosyal Bilgiler Öğretimi. Alkım Yayınevi, İstanbul.

Ezer, Feyzullah ve Aksüt, Selda (2018). "Sosyal Bilgiler Dersinde Drama Yönteminin Kullanılmasına İlişkin Öğretmen Görüşleri”. The Journal of Academic Social Science Studies, (71), ss. 91-112.

Gönen, Mübeccel ve Dalkılıç, Nursel Uyar (2000). Çocuk Eğitiminde Drama Yöntem ve Uygulamalar (3. bask1). Epsilon Yayıncılık, İstanbul.

İbiş, Ezgi (2017). Değerler Eğitimi Temelli Yaratıcı Drama Programının 5-6 Yaş Çocuklarının Sosyal Becerilerinin Gelişimine Etkisi. Yüksek lisans tezi, Dokuz Eylül Üniversitesi Eğitim Bilimleri Enstitüsü, İzmir.

İşyar, Özge Özgür (2017). Sınıf Öğretmenlerinin Eğitimde Drama Kullanımına İlişkin Yeterlilik Algıları ve Drama Kavramına Yönelik Metaforları İle Görüşlerinin İncelenmesi. Yüksek lisans tezi, Mersin Üniversitesi Eğitim Bilimleri Enstitüsü, Mersin.

Kadan, Ömer Faruk (2013). Yaratıcı Drama Yönteminin Ortaokul 7. Sınıf Öğrencilerinin İngilizce Dersindeki Başarı, Tutum ve Motivasyonlarına Etkisi. Yüksek lisans tezi, Mustafa Kemal Üniversitesi Sosyal Bilimler Enstitüsü, Hatay.

Kahriman, Musa (2014). İlkokul 3. Sınıf Hayat Bilgisi Dersi Benim Eşsiz Yuvam Temasındaki Konuların Drama Yöntemine Dayalı Öğretiminin Öğrencilerin İletişim, Empati Becerileri ve Değer Algıları Üzerine Etkisi. Yüksek lisans tezi, Mustafa Kemal Üniversitesi Sosyal Bilimler Enstitüsü, Hatay. 
Karadăg, Engin ve Çalışkan, Nihat (2008). Kuramdan-Uygulamaya İlköğretimde Drama (2. baskı). Arı Yayıncılık, Ankara.

Karaosmanoğlu, Gökhan (2015). Yaratıcı Drama Yönteminin 6. Sınıf Bilişim Teknolojileri ve Yazılım Dersi Alan Öğrencilerin Ders Başarılarına Etkisi. Yüksek lisans tezi, Ankara Üniversitesi Eğitim Bilimleri Enstitüsü, Ankara.

Koç, İhsan (2013). Öğretmenlerin Sosyal Bilgiler Dersinde Drama Yöntemini Uygulama ve Drama Tekniklerine İlişkin Yeterliliklerinin Belirlenmesi. Yüksek lisans tezi, Ahi Evran Üniversitesi Sosyal Bilimler Enstitüsü, Kırşehir.

Miles, Matthew B. ve Huberman, A. Michael (2016). Analizde İlk Adımlar. Ali Ersoy (Çev.), Sadegül Akbaba Altun ve Ali Ersoy (Çev. Ed.), Genişletilmiş Bir Kaynak Kitap: Nitel Veri Analizi içinde (ss. 50-88). 1994, Pegem Akademi, Ankara.

Morgül, Mahiye (2003). Eğitimde Yaratıcı Dramaya Merhaba (2. baskı). Kök Yayıncılık, Ankara.

Ömeroğlu, Esra; Ersoy, Özlem; Tezel Şahin, Fatma; Kandır, Adalet ve Turla, Ayşe (2003). Okul Öncesi Eğitimde Drama Teoriden Uygulamaya (1. bask1). Kök Yayıncılık, Ankara.

Önder, Alev (2012). Yaşayarak Öğrenme İçin Eğitici Drama Kuramsal Temellerle Uygulama Teknikleri ve Örnekleri (9. bask1). Nobel Akademik Yayınc1lık, Ankara.

Pektezel, Bilal (2017). Sosyal Bilgiler Dersinde Yer Alan Tarih Konularının Öğretiminde Drama Kullanımı: Bir Eylem Araştırması. Yüksek lisans tezi, Uşak Üniversitesi Sosyal Bilimler Enstitüsü, Uşak.

Saban, Ahmet (2009). "Öğretmen adaylarının öğrenci kavramına ilişkin sahip oldukları zihinsel imgeler". Türk Eğitim Bilimleri Dergisi, 7(2), ss. 281-326.

Saraç, Aylin (2015). Sosyal Bilgiler Dersinde Drama Yöntemi Kullanılmasının Tutum, Başarı ve Kalıcılığa Etkisi. Yüksek lisans tezi, Balıkesir Üniversitesi Sosyal Bilimler Enstitüsü, Balıkesir.

Sünbül, Ali Murat (2007). Öğretim İlke ve Yöntemleri. Çizgi Kitabevi, Ankara. 
F.Ezer-S.Aksüt $\quad$ 5. Sınıf Sosyal Bilgiler Dersinde Drama Yönteminin...

Tavşancıl, Ezel ve Aslan, Esra (2001). Sözel, Yazılı ve Diğer Materyaller İçin İçerik Analizi ve Uygulama Örnekleri (1. bask1). Epsilon Yayıncılık, İstanbul.

Yayla Ceylan, Şehnaz (2014). Dramatik Etkinlikler ve Dramanın Çocuğun Gelişimindeki Yeri. Esra Ömeroğlu (Ed.), Okul Öncesi Eğitimde Dramatik Etkinliklerden Dramaya Teoriden Uygulamaya içinde (ss. 17-43). Eğiten Kitap, Ankara.

Yıldırım, Ali ve Şimşek, Hasan (2016). Sosyal Bilimlerde Nitel Araştırma Yöntemleri. (16. baskı). Seçkin Yayıncılık, Ankara. 